\title{
Gene expression profiling of upregulated mRNAs in granulosa cells of bovine ovulatory follicles following stimulation with hCG
}

\author{
Jacques G. Lussier ${ }^{1 *}$, Mame N. Diouf ${ }^{1,2}$, Valérie Lévesque ${ }^{1}$, Jean Sirois ${ }^{1}$ and Kalidou Ndiaye ${ }^{1}$
}

\begin{abstract}
Background: Ovulation and luteinization of follicles are complex biological processes initiated by the preovulatory luteinizing hormone surge. The objective of this study was to identify genes that are differentially expressed in bovine granulosa cells (GC) of ovulatory follicles.

Methods: Granulosa cells were collected during the first follicular wave of the bovine estrous cycle from dominant follicles (DF) and from ovulatory follicles (OF) obtained $24 \mathrm{~h}$ following injection of human chorionic gonadotropin (hCG). A granulosa cell subtracted cDNA library (OF-DF) was generated using suppression subtractive hybridization and screened.
\end{abstract}

Results: Detection of genes known to be upregulated in bovine GC during ovulation, such as ADAMTS1, CAV1, EGR1, MMP1, PLAT, PLA2G4A, PTGES, PTGS2, RGS2, TIMP1, TNFAIP6 and VNN2 validated the physiological model and analytical techniques used. For a subset of genes that were identified for the first time, gene expression profiles were further compared by semiquantitative RT-PCR in follicles obtained at different developmental stages. Results confirmed an induction or upregulation of the respective mRNAs in GC of OF $24 \mathrm{~h}$ after hCG-injection compared with those of DF for the following genes: ADAMTS9, ARAF, CAPN2, CRISPLD2, FKBP5, GFPT2, KIT, KITLG, L3MBLT3, MRO, NUDT10, NUDT11, P4HA3, POSTN, PSAP, RBP1, SAT1, SDC4, TIMP2, TNC and USP53. In bovine GC, CRISPLD2 and POSTN mRNA were found as full-length transcript whereas L3MBLT3 mRNA was alternatively spliced resulting in a truncated protein missing the carboxy-terminal end amino acids, ${ }^{774} \mathrm{KNSHNEL}^{780}$. Conversely, L3MBLT3 is expressed as a full-length mRNA in a bovine endometrial cell line. The ${ }^{774} \mathrm{KNSHNEL}^{780}$ sequence is well conserved in all mammalian species and follows a SAM domain known to confer protein/protein interactions, which suggest a key function for these amino acids in the epigenetic control of gene expression.

Conclusions: We conclude that we have identified novel genes that are upregulated by hCG in bovine GC of OF, thereby providing novel insight into peri-ovulatory regulation of genes that contribute to ovulation and/or luteinization processes.

Keywords: Ovary, Follicle, Ovulation, Granulosa cells, Gene expression

\footnotetext{
* Correspondence: jacques.lussier@umontreal.ca

${ }^{1}$ Centre de recherche en reproduction et fertilité, Faculté de médecine

vétérinaire, Université de Montréal, 3200 Sicotte, St-Hyacinthe, Québec J2S

2M2, Canada

Full list of author information is available at the end of the article
} 


\section{Background}

In cattle, ovarian follicular development is characterized by two or three consecutive follicular waves per estrous cycle. Each wave involves the recruitment of a cohort of follicles at the diameter of 3- to 4-mm. A selection phase follows, in which a single follicle continues its development and becomes the dominant follicle (DF), whereas subordinate follicles degenerate by atresia [1]. The DF of the final wave of the estrous cycle pursues its growth and matures into an ovulatory follicle (OF) following the release of the preovulatory LH surge. The ovulatory process begins at the time when the endogenous preovulatory LH surge stimulates $G$ protein-coupled $\mathrm{LH} /$ human chorionic gonadotropin receptors (LHCGR) located on granulosa and theca cells. Activation of the LHCGR induces a developmental program in different compartments of the DF to ensure the release of a competent oocyte via changes in formation/organization of hyaluronan-rich cumulus extracellular matrix followed by rupture of follicular wall, and by formation of the corpus luteum through differentiation of granulosa and theca cells into luteal cells. These processes are controlled by the expression of many genes that are either up- or downregulated in a temporally and spatially distinct fashion. The mechanisms ensuring the transition from a DF into an OF are not fully understood [2]. This information is essential to advance our understanding of the cascade of events leading to ovulation and luteinization of the follicle, which may be further applied to enhance fertility.

Genes expressed in granulosa cells (GC) that control the growth of a bovine dominant or preovulatory follicle are rapidly downregulated as a consequence of post LH surgemediated increases in intracellular signaling [3, 4]. In conjunction with the termination of specific gene expression in preovulatory follicles, $\mathrm{LH} / \mathrm{hCG}$ induces expression of genes involved in ovulation and luteinization, as shown in rodents [5] or in the bovine species $[4,6,7]$. Most data on the temporal pattern of gene expression arising during ovulation have been obtained using RNA extracts from the immature eCG- and hCG-stimulated rodent ovaries. Moreover, the use of microarray in rodent or bovine studies are limited to genes present in the array, and results among bovine studies vary in relation to experimental design and treatment used $[4,6$, 7]. The objective of the present study was to identify candidate genes that are upregulated in GC of bovine preovulatory follicle in response to an ovulatory stimulus. The working hypothesis was that the transition from a DF into an OF results from transcriptional induction or upregulation of a subset of genes in GC. Gene expression was studied in GC because they represent an important compartment of the ovarian follicle involved in hormone synthesis and maturation of the oocyte [2]. The GC were obtained from hCG-induced OF and growing DF collected during the first follicular wave of the bovine estrous cycle. Gene expression analysis was achieved by use of suppression subtractive hybridization
(SSH) $[3,8]$ that results in enrichment of differentially expressed genes in OF, followed by the establishment of a GC subtracted cDNA library (OF-DF). The cDNA clones isolated from the subtracted library were validated for their differential expression pattern by cDNA macroarrays and characterized by sequencing. A subset of genes found to be differentially expressed by macroarrays were further validated by semiquantitative reverse transcriptase polymerase chain reaction (RT-PCR) performed on independent follicles and corpus luteum obtained at different developmental stage. Also, we undertook the characterization of the differentially expressed mRNA of cysteine-rich secretory protein LCCL domain-containing 2 (CRISPLD2), periostin (POSTN) and lethal (3) malignant brain tumor-like protein (L3MBTL3) full-length cDNAs since they were not experimentally characterized in the bovine species.

\section{Methods}

\section{Experimental animal model and sample preparations}

Normal cycling crossbred heifers were synchronized with one injection of $\mathrm{PGF}_{2 \alpha}$ (25 mg, im; Lutalyse, Upjohn, Kalamazoo, MI) given in the presence of a corpus luteum (CL). Behavioral estrus was monitored at $12 \mathrm{~h}$ intervals, from $48 \mathrm{~h}$ to $96 \mathrm{~h}$ following the $\mathrm{PGF}_{2 \alpha}$ injection. From the time of $\mathrm{PGF}_{2 \alpha}$ injection until ovariectomy, ovarian follicular development was monitored by daily transrectal ultrasonography performed with a real-time linear scanning ultrasound diagnostic system (LS-300; Tokyo Keiki Co, Ltd., Tokyo, Japan) equipped with a 7.5-MHz transducer probe. At each examination, the diameter of the $\mathrm{CL}$ and individual follicles $\geq 4 \mathrm{~mm}$ were measured at their largest crosssectional area using internal calipers. Following estrus synchronization by $\mathrm{PGF}_{2 \alpha}$, heifers were randomly assigned to the dominant follicle group (DF; $n=4$ ) or the ovulatory hCG-induced follicle group (OF; $\mathrm{n}=4)$. In the DF group, the ovary bearing the DF on the morning of day 5 of the estrous cycle (day $0=$ day of estrus) was obtained by ovariectomy (via colpotomy). The DF was defined as $>8 \mathrm{~mm}$ by ultrasonographic measurement and growing while subordinate follicles were either static or regressing [9]. The mean diameter of DF measured at the surface of the ovary was $10.4 \pm 0.3 \mathrm{~mm}$. The OF were obtained following an injection of $25 \mathrm{mg}$ of $\mathrm{PGF}_{2 \alpha}$ (Lutalyse) on day 7 to induce luteolysis, thereby maintaining the development of the DF of the first follicular wave into a preovulatory follicle [10]. An ovulatory dose of hCG (3000 IU, iv; APL, Ayerst Lab, Montréal, QC) was injected $36 \mathrm{~h}$ after the induction of luteolysis, and the ovary bearing the hCG-induced OF was collected by ovariectomy at $24 \mathrm{~h}$ after hCG injection. The mean diameter of OF was $12.9 \pm 0.3 \mathrm{~mm}$. Follicular fluid and mural GC with whole cumulus-oocyte complex were collected separately from individual DF or OF as described previously [9]. Additionally, GC and follicular fluid were collected from 2 to $4 \mathrm{~mm}$ follicles that were obtained from 
slaughterhouse ovaries representing a total of three pools of 20 small follicles (SF). These experiments were approved by the Animal Ethics Committee of the Faculty of Veterinary Medicine of the Université de Montréal. Concentrations of progesterone $\left(\mathrm{P}_{4}\right)$, estradiol-17 $\beta\left(\mathrm{E}_{2}\right)$ and their ratio $\left(\mathrm{P}_{4} / \mathrm{E}_{2}\right)$ were analyzed by RIA of follicular fluid as previously described [9]. The $\mathrm{E}_{2} / \mathrm{P}_{4}$ ratios were calculated for each sample: 1) $0.008,0.06$ and 0.01 for the three SF pools; 2) 17.3, 19.7, 14.3 and 63.4 for individual DF at day $5(n=4)$; and 3) $0.44,0.87,0.64$ and $0.27(n=4)$ for individual OF. CL at day 5 of the estrous cycle were obtained by ovariectomy from cows following ultrasound monitoring of follicular development and estrus synchronization as described above. The CL were dissected from the ovarian stroma, frozen in liquid nitrogen, and then stored at $-80{ }^{\circ} \mathrm{C}$ until RNA extraction. Total RNA was isolated from GC or CL by homogenization in lysis buffer (4 M guanidium isothiocyanate, $0.5 \% \mathrm{Na}-\mathrm{N}$-laurylsarcosine, $25 \mathrm{mM}$ NaCitrate, $\mathrm{pH} 7$ ), and total RNA sedimented on a cesium chloride cushion by ultracentrifugation as previously described [9]. The concentration of total RNA was quantified by measurement of optical density at $260 \mathrm{~nm}$, and quality was evaluated by visualizing the $28 \mathrm{~S}$ and $18 \mathrm{~S}$ ribosomal bands following electrophoretic separation on a formaldehyde denaturing $1 \%$ agarose gel with ethidium bromide.

\section{Suppression subtractive hybridization and differential hybridization screening}

To compare gene expression in GC collected from OF versus DF, the suppression subtractive hybridization $(\mathrm{SSH})$ was performed as previously described [8]. Identical amounts of total RNA $(2 \mu \mathrm{g})$ from four OF or four DF were pooled within treatment groups to decrease inter animal variation. To generate sufficient amounts of double-stranded cDNA for an SSH experiment, both OF and DF cDNAs were amplified separately using the SMART PCR cDNA synthesis kit. One microgram of total RNA from each pooled group was reverse transcribed with an oligo-dT30 primer [CDS: $5^{\prime}$-AAGCAGTGGTAA CAACGCAGAGTACT(30)(A/C/G/T) (A/G/C)-3'] and PowerScript (BD Biosciences Clontech) to generate the first strand $\mathrm{CDNA}$. Second cDNA strands were produced with the SMART II 5'-anchored oligo and PCR-amplified for 15 cycles using Advantage 2 DNA polymerase (BD Biosciences Clontech). PCR-generated OF and DF cDNAs were digested with RsaI to generate blunt-ended cDNA fragments [from 0.2 to 2 kilobases $(\mathrm{kb})$ ]. The OF cDNAs were subtracted against DF cDNAs (forward reaction: OFDF) using PCR-Select cDNA subtraction technology (User manual: PT1117-1; BD Biosciences Clontech) [8], and in a parallel experiment, the DF cDNAs were subtracted against the OF cDNAs (reverse reaction: DF-OF). The efficiency of subtraction was analyzed by comparing the abundance of cDNAs before and after subtraction by PCR using bovine gene-specific primers for a gene known to be induced by hCG, such as prostaglandin-endoperoxide synthase 2 (PTGS2), and a gene known to be downregulated by hCG, such as cytochrome P450, family 19, subfamily 1 (CYP19A1). PCR amplification was performed using Advantage 2 DNA polymerase (BD Biosciences Clontech), and $5-\mu \mathrm{l}$ aliquots were removed following determined numbers of PCR cycles. The amplified products were resolved on a $2 \%$ agarose gel in TAE buffer (40 mM Trisacetate, $1 \mathrm{mM}$ EDTA, $0.5 \mu \mathrm{g} / \mathrm{ml}$ ethidium bromide). The difference in the number of cycles needed to generate an equal amount of the corresponding PCR product in subtracted and unsubtracted samples served to indicate the subtraction efficiency.

The subtracted cDNAs were cloned into the pT-Adv plasmid (BD Biosciences Clontech) to construct the OF-DF subtracted library and used to transform competent TOP10F' Escherichia coli as previously described [11]. The subtracted OF-DF cDNA library (940 individual colonies) was used to establish macroarrays for differential screening following previously described methodologies [8]. The insert of each cDNA clone was amplified in 96-well plates by PCR (28 cycles) using the PCR-nested primers 1 and 2R and AmpliTaq DNA polymerase (Roche Molecular Systems Inc., Laval, QC). To establish the cDNA macroarrays, an aliquot of each amplification product was denatured in $0.3 \mathrm{M} \mathrm{NaOH}$ with $5 \%$ bromophenol blue, and $10 \mu \mathrm{l}$ were vacuum transferred with a 96-well dot-blot apparatus onto nylon membranes (Hybond-N ${ }^{+}$, GE Healthcare Life Sciences), which were then exposed to $150 \mathrm{~mJ}$ ultraviolet light (UV) to perform DNA cross-linking (Gs Gene Linker; Bio-Rad, Mississauga, ON). Control cDNAs (CYP19A1, PTGS2) were transferred onto the macroarrays. For each 96-well plate, two identical cDNA macroarray replicate membranes were generated. The OFDF and DF-OF cDNA pools were used to generate complex hybridization probes for differential screening of macroarrays of the OF-DF cDNA library. Probes were obtained by performing the secondary nested PCR and were then purified (QIAquick PCR Purification Kit; Qiagen Inc., Mississauga, $\mathrm{ON})$. To prevent nonspecific interaction of the probes to cDNAs on macroarrays during hybridization, the adaptors were removed by three successive digestions with AfaI, SmaI, and EagI; the cDNA pools were again purified (QIAquick; PCR Purification Kit, Qiagen Inc.) and $100 \mathrm{ng}$ were labeled with $\left[\alpha^{32} \mathrm{P}\right]-\mathrm{dCTP}$ by random priming (Megaprime DNA Labeling System; GE Healthcare Life Sciences). The radioactive probes were purified (QIAquick Nucleotide Removal kit; Qiagen Inc.) and quantified using a beta counter. The hybridization and washing conditions of macroarrays were performed as previously described [8]. Equal amounts of each heat-denatured cDNA probe (OF-DF, DF-OF) were used to hybridize each replicate of the OF-DF macroarray membrane. Following washing, membranes were exposed to a phosphor screen for $4 \mathrm{~h}$ and the images were digitized 
(Storm 840; GE Healthcare Life Sciences). The differentially hybridizing cDNA clones were characterized by DNA sequencing and their differential expression profiles were further validated by semiquantitative RT-PCR analysis from independent follicles obtained at different developmental stages.

Identification of differentially expressed cDNAs were obtained by sequencing. The cDNA clones identified as differentially expressed by the OF-DF subtracted probe were amplified by PCR for 15 cycles with the corresponding PCR-nested 1 and PCR-nested 2 oligos from the PCR product generated initially for the macroarrays. The PCR product was purified (Qiagen Inc.) and verified by agarose gel analysis for the presence of a single cDNA band before proceeding with sequencing. Sequencing reactions were performed on cDNA clones via the dideoxy sequencing method (Big Dye Terminator 3.0; ABI Prism, Applied BioSystem, PE, Branchburg, NJ) using the oligos PCRNested 1 or 2, and sequencing reactions were analyzed on an ABI Prism 310 sequencer (Applied Biosystems). Nucleic acid sequences were analyzed by BLAST (Basic Local Alignment Search Tool) against GenBank data banks.

\section{Gene expression analysis}

The cDNA clones that were identified as differentially expressed in the SSH differential screening experiment were used to compare their differential expression pattern in GC collected from follicles at different developmental stages and CL, using semiquantitative RT-PCR/Southern blot analysis (also called virtual Northern blot analysis; User manual: PT1117-1; BD Biosciences Clontech). To perform semiquantitative RT-PCR/Southern blot analysis, total RNA $(1 \mu \mathrm{g})$ from GC (SF, DF, OF) or CL (D5) were reverse transcribed using SMART PCR cDNA synthesis technology (BD Biosciences Clontech, Mississauga, $\mathrm{ON}$ ) as previously described [8]. The cDNA products for each follicle or CL along with molecular weight standards (1 kb ladder, $\phi \mathrm{X}$ 174-RF/Hae III and 1/Hind III; GE Healthcare Life Sciences) were separated on agarose gel, then transferred onto nylon membrane. Gene-specific probes derived from SSH cDNA fragments were generated by PCR (20 cycles) using the primers PCR Nested 1 and PCR-Nested 2R. Glyceraldehyde-3-phosphate dehydrogenase $(G A P D H)$ probe was used as a constitutively expressed gene. Purified cDNA probes were labeled with $\left[\alpha^{32} \mathrm{P}\right]-\mathrm{dCTP}$ as described above. Semiquantitative RT-PCR/ Southern membranes were prehybridized, hybridized, and washed as described [8]. Membranes were exposed to phosphor screen and the images were digitized (Storm 840; GE Healthcare Life Sciences).

Semiquantitative RT-PCR analysis was performed for genes that showed a weak signal by RT-PCR/Southern blot or to analyze differentially spliced transcripts [8]. Genespecific primers were designed into the open reading frame of the cDNA sequence and are described in Table 1. SMART
cDNAs were generated as described above, and $1 \mu \mathrm{l}$ was used in a 25- $\mu$ l PCR reaction using the Advantage 2 DNA polymerase. The number of PCR cycles were limited and optimized to fall in the linear range of amplification reaction for each gene to be analyzed. The PCR reactions were separated on a $2 \%$ TAE-agarose gel with ethidium bromide, PCR products were visualized by UV, and the images digitized. The digitized signals for each gene obtained either by semiquantitative RT-PCR/Southern blot or semiquantitative RTPCR were analyzed by densitometry using ImageQuant software (GE Healthcare Life Sciences).

\section{Characterization of bovine POSTN, CRISPLD2 and L3MBTL3 cDNAs}

Isolation of full-length bovine periostin (POSTN), cysteine-rich secretory protein LCCL domain containing 2 (CRISPLD2) and lethal (3) malignant brain tumor-like protein (L3MBTL3) cDNAs was performed by screening a size-selected cDNA library for each of the cDNA as described [11], since their respective full-length cDNAs were not experimentally characterized in the bovine species. Initially, the respective sizes of the full-length cDNA were estimated by performing a semiquantitative RT-PCR/Southern blot analysis with cDNA pool generated from hCG-stimulated GC and hybridized with radioactive probes for POSTN, CRISPLD2 or L3MBTL3 derived from the SSH screening experiment (Table 2). Once the size of the full-length bovine POSTN, CRISPLD2 and L3MBTL3 cDNAs were determined, total SMART cDNAs from hCG-stimulated GC were sizefractionated by agarose gel electrophoresis, and cDNAs from 2.5 to $3.5 \mathrm{~kb}$ for POSTN, and from 4 to $6 \mathrm{~kb}$ for CRISPLD2 and L3MBTL3 were purified and used to construct a size-selected cDNA library based on the pDrive plasmid (Qiagen PCR cloning kit; Qiagen) that was then screened by radioactive hybridization as described [11]. Positive POSTN, CRISPLD2 and L3MBTL3 hybridizing bacterial colonies were grown, their plasmid contents were isolated (QIA-prep, Qiagen), and the size of the cloned cDNA was analyzed following an EcoR1 digestion and gel electrophoresis analysis. The cDNAs were sequenced via the dideoxy sequencing method (Big Dye Terminator 3.0; ABI Prism, Applied BioSystems, PE) that were analyzed on an ABI Prism 310 sequencer (Applied Biosystems). Nucleic acid sequences were analyzed by BLAST against GenBank data banks.

\section{Statistical analysis}

Gene-specific signals generated for semiquantitative RTPCR/Southern blot and semiquantitative RT-PCR analyses were normalized with corresponding GAPDH signals for each sample. Homogeneity of variance between follicular groups and CL was verified by O'Brien and BrownForsythe tests. Corrected values of gene-specific mRNA 
Table 1 Gene-specific primers used in SSH and semiquantitative RT-PCR analysis

\begin{tabular}{|c|c|c|c|}
\hline Gene & & Primer Sequence $\left(5^{\prime}-3^{\prime}\right)^{a}$ & GenBank accession number \\
\hline \multirow[t]{2}{*}{ ADAMTS1 } & Fwd & CGATAAATGTGGCATCTGTGGAG & NM_001101080 \\
\hline & Rv & AGCCCACACGACTTGGAACACTC & \\
\hline \multirow[t]{2}{*}{ ADAMTS9 } & Fwd & GGAAATCCGTATTGGGAATGCTG & NM_001206573 \\
\hline & Rv & CATCTAGCCTGCTGTACTTGGC & \\
\hline \multirow[t]{2}{*}{ ARAF } & Fwd & TCTAACAACATCTTCCTGCACGAG & NM_001014964 \\
\hline & Rv & GGCAACTCATCAGCCTGGGTAC & \\
\hline \multirow[t]{2}{*}{ CAPN2 } & Fwd & TGAGGGCTTCGAGGACTTCACTG & NM_001103086 \\
\hline & Rv & GCTGTCACTGGTGAGTGTGTCAG & \\
\hline \multirow[t]{2}{*}{ CRISPLD2 } & Fwd & CTATGGGATCCTGGACGACAGG & AY369781 \\
\hline & Rv & CCTGCAAGTTCACTGCCTGACG & \\
\hline \multirow[t]{2}{*}{ CYP19A1 } & Fwd & GTCCGAAGTTGTGCCTATTGCCAGC & NM_174305 \\
\hline & Rv & CCTCCAGCCTGTCCAGATGCTTGG & \\
\hline \multirow[t]{2}{*}{ FKBP4 } & Fwd & TCCATTCCTCGTGAATGAATGTCC & NM_001034322 \\
\hline & Rv & TGAACCTTCAGCAACGTGCAGAG & \\
\hline \multirow[t]{2}{*}{ FKBP5 } & Fwd & ACTGGAGCAGGCTGCCATTGTC & XM_615814 \\
\hline & Rv & CTTGAACATGTTGGCATAGATTCTG & \\
\hline \multirow[t]{2}{*}{ GAPDH } & Fwd & TGTTCCAGTATGATTCCACCCACG & NM_001034034 \\
\hline & Rv & CTGTTGAAGTCGCAGGAGACAACC & \\
\hline \multirow[t]{2}{*}{ KITLG1 } & Fwd & AGTAACCGTGTGACTGATGATGTG & NM_174375 \\
\hline & Rv & AGAATGCTGGCAATGCTACGGCTG & \\
\hline \multirow[t]{2}{*}{ KITLG2 } & Fwd & AGTAACCGTGTGACTGATGATGTG & NM_174375 \\
\hline & Rv & CTAAGGGAGCTGGCTGCAACAG & \\
\hline \multirow[t]{2}{*}{ L3MBTL3 } & Fwd & GTTATTACAGATGAGAGTGAGATGG & AY437805 \\
\hline & Rv & ACTTAAAGGACAGAAAGACGGC & \\
\hline L3MBTL3 & Fwd & CTTACCTGGATGTGAAGAACATGG & AY437805 \\
\hline (3'end of ORF) & Rv & CTGCAAGGTCTAAGACAGAGCTC & \\
\hline \multirow[t]{2}{*}{ MMP1 } & Fwd & CTTGGACTTGCTCATTCTACTGAC & NM_174112 \\
\hline & Rv & GGCATCGATGCTCTTCACCGTTC & \\
\hline \multirow[t]{2}{*}{ MRO } & Fwd & GGTGAGTTCTGAAGTCATCCATG & BC146146 \\
\hline & Rv & CCTGGTGTGCCGACCACCTTC & \\
\hline \multirow[t]{2}{*}{ NUDT10 } & Fwd & GACAGGTGAGCTCTITCACACTC & NM_001035488 \\
\hline & Rv & GGAGTTATGTCTAGAGGCACAGTC & \\
\hline \multirow[t]{2}{*}{ NUDT11 } & Fwd & GAACAGCAAAGATGTCCAGGATTG & NM_001101296 \\
\hline & Rv & CACACACATGGTGCCTGGAGAG & \\
\hline \multirow[t]{2}{*}{ P4HA3 } & Fwd & TTGGCAAGGTGGCCTATGACATG & NM_001001598 \\
\hline & Rv & CTGGAGCAGCAGGTAAGGACTG & \\
\hline \multirow[t]{2}{*}{ POSTN } & Fwd & CCAAAGCCCACTGCCAGTTCTC & AY445072 \\
\hline & Rv & GAAAGCCACTTTGATGTGAAGAATGAG & \\
\hline \multirow[t]{2}{*}{ PSAP } & Fwd & CTTCCTCCTGTACCCTCAGGAC & NM_174161 \\
\hline & Rv & GGGATGACGTTCTCTGAGACCAC & \\
\hline \multirow[t]{2}{*}{ PTGS2 } & Fwd & GCATTCTTTGCCCAGCACTTCACCC & NM_174445 \\
\hline & Rv & CTATCAGGATTAGCCTGCTTGTCTGG & \\
\hline RBP1 & Fwd & CGGTCGACTITACCGGGTACTG & NM_001025343 \\
\hline
\end{tabular}


Table 1 Gene-specific primers used in SSH and semiquantitative RT-PCR analysis (Continued)

\begin{tabular}{|c|c|c|c|}
\hline Gene & & Primer Sequence $\left(5^{\prime}-3^{\prime}\right)^{a}$ & GenBank accession number \\
\hline & Rv & GTCATGTCACTCATTCCTAGAGAC & \\
\hline \multirow[t]{2}{*}{ SDC4 } & Fwd & TCCGAGAAACTGAGGTCATCGAC & XM_584869 \\
\hline & Rv & GGTACACCAGCAGCAGCACGAG & \\
\hline \multirow[t]{2}{*}{ TIMP1 } & Fwd & CGTCATCAGGGCCAAGTTCGTG & NM_174471 \\
\hline & Rv & GCAAGGACTGCCAGGTGCACAG & \\
\hline \multirow[t]{2}{*}{ TIMP2 } & Fwd & TGCAATGCAGACATAGTGATCAGG & NM_174472 \\
\hline & Rv & CGCTTCTCTTGATGCAGGCGAAG & \\
\hline \multirow[t]{2}{*}{ TNC } & Fwd & CTATGTGCCCATTGCAGGAGGTG & NM_001078026 \\
\hline & Rv & AACTTGGTGGTGATGGTTGAGCTC & \\
\hline \multirow[t]{2}{*}{ USP53 } & Fwd & GAGAGCATACCCACCAGTCAGATG & BC149007 \\
\hline & Rv & GTTACTTTGACATCAGGAGTAGAGTC & \\
\hline
\end{tabular}

Fwd foward primer, Rv Reverse primer

${ }^{\mathrm{a}}$ All primers were designed and validated by the authors

levels were compared between follicular and CL groups by one-way ANOVA. When ANOVA indicated significant differences $(P<0.05)$, multiple comparisons of individual means for SF, DF, OF and CL groups were compared by the Tukey-Kramer test $(P<0.05)$. Pearson's correlation $(P<0.05)$ analysis was used to compare amplicon levels for KITLG1 and KITLG2. Data were presented as least-square means \pm SEM. Statistical analyses were performed using JMP software (SAS Institute, Inc.).

\section{Results}

\section{Identification of differentially expressed genes by $\mathrm{SSH}$}

A cDNA library containing transcripts that are upregulated by hCG in GC was constructed by subtracting DF cDNAs from OF cDNAs (OF-DF). Reverse subtraction was also performed as a control and consisted of OF cDNAs subtracted from DF cDNAs (DF-OF). PCR amplification analysis was used to verify the efficiency of the subtraction procedure by comparing the expression of reference genes such as PTGS2 in OF and CYP19A1 in DF, before and after subtraction. In the OF sample, the PTGS2 PCR product was observed after 18 cycles but was undetectable in the DF sample. In the OF-DF subtracted sample, the PCRamplified PTGS2 fragment was detected after 13 cycles, revealing that PTGS2 cDNA had been efficiently enriched in the subtracted OF-DF sample when compared with unsubtracted OF sample, confirming the effectiveness of the subtraction (validation of subtraction is presented in a Additional file 1: Figure S1). Subtracted cDNAs were then cloned into plasmid vector to generate the OF-DF cDNA library. Differential hybridization screening was performed on the randomly selected bacterial colonies to eliminate false-positive clones. Colonies were spotted onto two identical sets of macroarrays, and the OF-DF or DF-OF subtracted cDNA preparations were used as probes to hybridize macroarrays. On each membrane, PTGS2 and
CYP19A1 cDNAs were spotted as controls. Selection of differentially expressed cDNA clones was achieved by comparing signal intensities between the two macroarrays as defined by the following criteria. Positive clones hybridized with the OF-DF subtracted probes but not with the reverse subtracted probes, DF-OF. Representative differential screening results are illustrated in Additional file 1: Figure S2). Of the initial 940 clones, differential screening identified 279 positives as defined by the selection criteria based on comparing differential intensity of the signal. After visualization on agarose gels of PCR products derived from these clones followed by their sequencing, 261 clones generated sequencing results of adequate quality to be analyzed by BLAST against GenBank databases. Table 2 lists all the compared sequences with an example for each entry that was deposited in GenBank, as well as their frequency of identification by differential screening of the OF-DF library. This comparison revealed that $89.7 \%(234 / 261)$ corresponded to 60 non-redundant known genes, and 10.3\% (27/261) corresponded to express sequence tags (EST). The BLAST analysis of these ESTs against the bovine genome revealed that 24 ESTs were associated with transcribed loci, either introns or untranslated regions (UTR) of mRNA, of defined genes as indicated in brackets for each EST (Table 2) whereas three ESTs were considered novel transcribed loci.

\section{Analysis of mRNA expression}

Genes identified by macroarray analysis as upregulated in GC following stimulation by hCG were further validated on the basis of their frequency of identification in the OF-DF subtracted library (Table 2). Validation was performed initially by semiquantitative RT-PCR/ Southern blot analysis using mRNA samples derived from GC collected from independent follicles at different developmental stages (SF, DF, OF) and CL obtained at 
Table 2 Genes found to be differentially expressed in bovine granulosa cells of OF compared to DF

\begin{tabular}{|c|c|c|c|c|c|c|}
\hline Gene & $\begin{array}{l}\text { Accession } \\
\text { Number }^{\mathrm{a}}\end{array}$ & Freq $^{b}$ & Accession Number ${ }^{c}$ & $\begin{array}{l}\text { Identity } \\
(\%)^{d}\end{array}$ & $\begin{array}{l}\mathrm{E} \\
\text { value }\end{array}$ & Description ${ }^{\mathrm{e}}$ \\
\hline$\overline{A C T G 1}$ & EG565281 & 3 & NM_001033618 & $100 \%$ & 0 & BT Actin gamma 1 \\
\hline ADAMTS1 & GR508913 & 1 & NM_001101080 & $100 \%$ & $2 \mathrm{e}^{-126}$ & BT ADAM metallopeptidase with thrombospondin type 1 motif 1 \\
\hline APP & EG565335 & 1 & NM_001076796 & $100 \%$ & $e^{-107}$ & BT Amyloid beta precursor protein \\
\hline ARAF & EG565327 & 4 & NM_001014964 & $100 \%$ & 0 & BT A-Raf proto-oncogene. Serine/threonine kinase \\
\hline ASB9 & EG565323 & 2 & AY438595 & $99 \%$ & $4 e^{-179}$ & BT Ankyrin repeat and SOCS box-containing 9 \\
\hline BIRC2 & EG565293 & 1 & XM_015466434 & $100 \%$ & $2 e^{-67}$ & BT Baculoviral inhibitor of apoptosis repeat containing 2 \\
\hline CAPN2 & EG565332 & 1 & NM_001103086 & $100 \%$ & $8 e^{-57}$ & BT Calpain 2, (m/II) large subunit \\
\hline CAV1 & EG565338 & 20 & AY823915 & $100 \%$ & 0 & BT Caveolin 1 \\
\hline CD83 & EG565265 & 1 & NM_001046590 & $99 \%$ & 0 & BT CD83 molecule \\
\hline CDC42SE2 & EG565271 & 1 & NM_001102537 & $96 \%$ & $2 \mathrm{e}^{-180}$ & BT CDC42 small effector 2 \\
\hline CRISPLD2 & EG565333 & 16 & AY369781 & $100 \%$ & 0 & BT Cysteine-rich secretory protein LCCL domain containing 2 \\
\hline CSRP3 & EG565284 & 1 & NM_001024689 & $99 \%$ & $3 e^{-165}$ & BT Cysteine and glycine-rich protein 3 \\
\hline CTSK & EG565324 & 1 & NM_001034435 & $100 \%$ & $5 e^{-168}$ & BT Cathepsin K \\
\hline DHTKD1 & EG565315 & 1 & NM_001205838 & $100 \%$ & $3 e^{-170}$ & BT Dehydrogenase E1 and transketolase domain containing 1 \\
\hline EGR1 & EG565268 & 1 & AY924307 & $98 \%$ & $9 e^{-127}$ & BT Early growth response 1 \\
\hline EIF4E3 & EG565311 & 1 & NM_001102306 & $99 \%$ & $e^{-179}$ & BT Eukaryotic translation initiation factor $4 \mathrm{E}$ family member 3 \\
\hline FKBP5 & EG565325 & 6 & NM_001192862 & $100 \%$ & 0 & BT FK506-binding protein 5 \\
\hline GEM & EG565288 & 2 & NM_001083732 & $100 \%$ & 0 & BT GTP binding protein overexpressed in skeletal muscle \\
\hline GFPT2 & EG565318 & 5 & NM_001076883 & $99 \%$ & $4 e^{-168}$ & BT Glutamine-fructose-6-phosphate transaminase 2 \\
\hline GRIA3 & EG565320 & 3 & NM_001206059 & $99 \%$ & $2 e^{-166}$ & BT Glutamate ionotropic receptor AMPA type subunit 3 \\
\hline KIT & EG565345 & 1 & XM_005207937 & $99 \%$ & $7 e^{-110}$ & BT KIT proto-oncogene receptor tyrosine kinase \\
\hline KITLG & EG565276 & 5 & NC_007303 & $99 \%$ & 0 & BT KIT ligand \\
\hline L3MBTL3 & EG565310 & 2 & AY437805 & $100 \%$ & $7 e^{-73}$ & BT Histone methyl-lysine binding protein \\
\hline$L R I G 1$ & EG565303 & 1 & XM_002696962 & $100 \%$ & $2 e^{-84}$ & BT Leucine-rich repeats and immunoglobulin-like domains 1 \\
\hline MAOA & EG565344 & 4 & NM_181014 & $99 \%$ & $2 e^{-109}$ & BT Monoamine oxidase A \\
\hline MMP1 & GR508914 & 3 & NM_174112 & $100 \%$ & $8 e^{-83}$ & BT Matrix metallopeptidase 1 \\
\hline MORF4L1 & EG565343 & 1 & NM_001035448 & $98 \%$ & $4 e^{-38}$ & BT Mortality factor 4 like 1 \\
\hline$M R O$ & EG565273 & 4 & XM_005224181 & $100 \%$ & $1 e^{-95}$ & BT Maestro \\
\hline NT5E & EG565299 & 1 & NM_174129 & $100 \%$ & 0 & BT 5'-Nucleotidase, ecto \\
\hline NUDT10 & GR508915 & 2 & NM_001035488 & $100 \%$ & $2 e^{-138}$ & BT Nudix hydrolase 10 \\
\hline NUDT11 & EG565272 & 3 & NM_001101296 & $100 \%$ & 0 & BT Nudix hydrolase 11 \\
\hline P4HA3 & EG565269 & 2 & NM_001001598 & $100 \%$ & $1 e^{-96}$ & BT Propyl 4-hydroxylase subunit alpha 3 \\
\hline PAPSS2 & EG565283 & 1 & XM_583370 & $99 \%$ & 0 & BT 3'-Phosphoadenosine 5'-phosphosulfate synthase 2 \\
\hline$P I R$ & EG565279 & 1 & NM_001102358 & $100 \%$ & $1 e^{-101}$ & BT Pirin (iron-binding nuclear protein) \\
\hline PLA2G4A & EG565305 & 1 & AY363688 & $100 \%$ & $4 e^{-164}$ & BT Phospholipase A2 group IVA \\
\hline PLAT & EG565294 & 8 & NM_174146 & $99 \%$ & 0 & BT Plasminogen activator, tissue type \\
\hline POSTN & EG565275 & 33 & AY445072 & $100 \%$ & 0 & BT Periostin \\
\hline PSAP & EG565278 & 2 & NM_174161 & $99 \%$ & $8 e^{-89}$ & BT Prosaposin \\
\hline PTGES & EG565342 & 1 & AY032727 & $100 \%$ & $1 e^{-122}$ & BT Prostaglandin E synthase \\
\hline PTGS2 & EG565287 & 24 & AF031698 & $100 \%$ & 0 & BT Prostaglandin-endoperoxide synthase 2 \\
\hline PTX3 & EG565317 & 2 & NM_001076259 & $98 \%$ & $3 e^{-61}$ & BT Pentraxin \\
\hline RBP1 & EG565267 & 1 & NM_001025343 & $99 \%$ & $5 e^{-101}$ & BT Retinol binding protein 1 \\
\hline RGS2 & EG565346 & 4 & NM_001075596 & $100 \%$ & $7 e^{-130}$ & BT Regulator of G-protein signaling 2 \\
\hline
\end{tabular}


Table 2 Genes found to be differentially expressed in bovine granulosa cells of OF compared to DF (Continued)

\begin{tabular}{|c|c|c|c|c|c|c|}
\hline Gene & $\begin{array}{l}\text { Accession } \\
\text { Number }^{\mathrm{a}}\end{array}$ & Freq $^{b}$ & Accession Number ${ }^{c}$ & $\begin{array}{l}\text { Identity } \\
(\%)^{d}\end{array}$ & $\begin{array}{l}\text { E } \\
\text { value }\end{array}$ & Description $^{e}$ \\
\hline RND3 & EG565300 & 1 & NM_001099104 & $100 \%$ & $1 \mathrm{e}^{-127}$ & BT Rho family GTPase 3 \\
\hline SAT1 & EG565349 & 26 & NM_001034333 & $99 \%$ & 0 & BT Spermidine/spermine N1-acetyltransferase 1 \\
\hline SDC4 & EG565289 & 3 & XM_584869 & $99 \%$ & $1 e^{-136}$ & BT Syndecan 4 \\
\hline SEHIL & EG565340 & 1 & NM_001103089 & $99 \%$ & $1 e^{-158}$ & BT SEH1-like nucleoporin \\
\hline SLC25A17 & EG565266 & 1 & NM_001045948 & $99 \%$ & 0 & BT Solute carrier family 25 member 17 \\
\hline SOX4 & EG565285 & 1 & NC_007324 & $99 \%$ & $8 e^{-173}$ & BT SRY-box 4 \\
\hline SULT1A1 & EG565308 & 1 & NM_177521 & $99 \%$ & $2 e^{-99}$ & BT Sulfotransferase family 1 A member 1 \\
\hline SULT1E1 & GR508916 & 2 & NM_177488 & $99 \%$ & $4 e^{-60}$ & BT Sulfotransferase family $1 \mathrm{E}$ member 1 \\
\hline TIMP1 & GR508917 & 3 & NM_174471 & $100 \%$ & $2 e^{-90}$ & BT TIMP metallopeptidase inhibitor 1 \\
\hline TIMP2 & EG565302 & 1 & NM_174472 & $99 \%$ & $5 e^{-163}$ & BT TIMP metallopeptidase inhibitor 2 \\
\hline TMEM176B & EG565301 & 1 & NM_001099145 & $99 \%$ & $3 e^{-165}$ & BT Transmembrane protein 176B \\
\hline TMSB4X & EG565291 & 3 & NM_001113231 & $99 \%$ & $5 e^{-173}$ & BT Thymosin beta $4, \mathrm{X}$-linked \\
\hline TMSB10 & EG565264 & 1 & NM_174623 & $100 \%$ & $2 e^{-131}$ & BT Thymosin beta 10 \\
\hline TNC & EG565326 & 2 & NM_001078026 & $99 \%$ & 0 & BT Tenascin C \\
\hline TNFAIP6 & EG565319 & 5 & NM_001007813 & $99 \%$ & 0 & BT Tumor necrosis factor alpha-induced protein 6 \\
\hline USP53 & EG565304 & 1 & XM_015463685 & $100 \%$ & $8 e^{-78}$ & BT Ubiquitin specific peptidase 53 \\
\hline VNN2 & EG565337 & 2 & NM_001163920 & $100 \%$ & 0 & BT Vanin 2 \\
\hline EST & EG565334 & 1 & AC_000158 & $100 \%$ & $3 e^{-74}$ & BT transcribed locus, chromosome 1 \\
\hline EST & EG565313 & 8 & AC_000159 & $99 \%$ & $3 e^{-143}$ & BT transcribed locus, chromosome 2 [3'UTR of TNFAIP6] \\
\hline EST & EG565321 & 4 & AC_000159 & $100 \%$ & 0 & BT transcribed locus, chromosome 2 [intron 1 of TNFAIP6] \\
\hline EST & EG565339 & 2 & AC_000159 & $99 \%$ & 0 & BT transcribed locus, chromosome 2 [intron 1 of TNFAIP6] \\
\hline EST & EG565316 & 1 & AC_000159 & $99 \%$ & 0 & BT transcribed locus, chromosome 2 [intron 1 of TNFAIP6] \\
\hline EST & EG565341 & 2 & AC_000159 & $99 \%$ & $4 e^{-70}$ & BT transcribed locus, chromosome 2 [3'UTR of TNFAIP6] \\
\hline EST & EG565336 & 1 & AC_000161 & $99 \%$ & 0 & $\begin{array}{l}\text { BT transcribed locus, chromosome } 4 \text { [3'UTR of } \\
\text { Ubiquitin-conjugated enzyme E2H; UBE2H] }\end{array}$ \\
\hline EST & EG565296 & 1 & AC_000163 & $100 \%$ & 0 & BT transcribed locus, chromosome 6 \\
\hline EST & EG565307 & 1 & AC_000167 & $98 \%$ & $4 e^{-106}$ & $\begin{array}{l}\text { BT transcribed locus, chromosome } 10 \text { [intron } 2 \text { of } \\
\text { Nidogen 2; NID2] }\end{array}$ \\
\hline EST & EG565328 & 1 & AC_000169 & $99 \%$ & 0 & $\begin{array}{l}\text { BT transcribed locus, chromosome } 12 \text { [intron } 1 \text { of } \\
\text { Glypican-6; GPC6] }\end{array}$ \\
\hline EST & EG565274 & 1 & AC_000169 & $99 \%$ & $3 e^{-133}$ & BT transcribed locus, chromosome 12 \\
\hline EST & EG565270 & 1 & AC_000172 & $99 \%$ & $8 \mathrm{e}^{-175}$ & $\begin{array}{l}\text { BT transcribed locus, chromosome } 15 \text { [3'UTR of } \\
\text { Rho GTPase activating } \\
\text { protein 20; ARHGAP20] }\end{array}$ \\
\hline EST & EG565314 & 1 & AC_000179 & $100 \%$ & $6 \mathrm{e}^{-156}$ & $\begin{array}{l}\text { BT transcribed locus, chromosome } 22 \text { [intron } 28 \text { of } \\
\text { ADAM metallopeptidase with thrombospondin } \\
\text { type } 1 \text { motif 9; ADAMTS9] }\end{array}$ \\
\hline EST & EG565295 & 1 & AC_000180 & $100 \%$ & 0 & $\begin{array}{l}\text { BT transcribed locus, chromosome } 23 \text { [intron of } \\
\text { runt related transcription } \\
\text { factor 2; RUNX2] }\end{array}$ \\
\hline EST & EG565309 & 1 & AC_000185 & $99 \%$ & 0 & $\begin{array}{l}\text { BT transcribed locus, chromosome } 28 \text { ['UTR of } \\
\text { Sterile alpha motif domain containing 8; SAMD8] }\end{array}$ \\
\hline
\end{tabular}


Day 5 of the estrous cycle. For these analyses, mRNAs were reverse transcribed into cDNAs, separated on agarose gel, and transferred onto membranes that were then hybridized to cloned SSH cDNA fragments as described in Table 2. Messenger RNA expression for tissue plasminogen activator (PLAT), early growth response 1 (EGR1), tumor necrosis factor alpha-induced protein 6 (TNFAIP6), regulator of G-protein signaling 2 (RGS2), spermidine/spermine N1-acetyltransferase 1 (SAT1), glutamine-fructose-6-phosphate transaminase 2 (GFPT2), KIT proto-oncogen receptor tyrosine kinase $(K I T)$ and periostin (POSTN), showed a statistically significant increase or induction by hCG in GC of OF (Fig. 1). When mRNA signals observed for GC of OF were compared with that of DF, expression of RGS2 and POSTN were induced, whereas for other genes, the increase was 32.8-fold for PLAT, 24.7-fold for EGR1, 7.9-fold for TNFAIP6, 18fold for SAT1, 26.8-fold for GFPT2 and 23.6-fold for KIT.

A semiquantitative RT-PCR assay was performed on selected genes described in Table 2 to confirm and compare their mRNA differential expression pattern in GC of hCGinduced OF. For this procedure, cDNAs were generated from total RNA, and the number of PCR cycles was optimized for each gene. All of the genes analyzed in this manner showed a statistically significant increase in hCGtreated GC of OF compared to that of DF (Fig. 2). Messenger RNA expression for KIT ligand (KITLG1) and isoform 2, KITLG2, each showed a 6.7-fold increase in GC of OF compared to that of DF (Fig. 2a). Intensity of amplicon signals obtained for KITLG1 and KITLG2 were highly correlated $(r=0.956)$. The FK506 binding protein 5 (FKBP5) mRNA was mainly observed in OF with a 8.6-fold increase in expression when compared to DF. Conversely, FK506 binding protein 4 (FKBP4) used as control, showed no difference in expression between follicular stages but was reduced by 2.8fold in CL when compared to OF. Syndecan 4 (SDC4) transcript was mainly expressed in $\mathrm{GC}$ of $\mathrm{OF}$ wherein a 4.5 -fold higher expression level was observed compared to DF. Calpain 2 (m/II) large subunit (CAPN2) transcript was detected in all groups and showed a 7.1-fold higher expression level in GC of OF compared to DF. The prolyl 4-hydroxylase subunit alpha 3 (P4HA3) mRNA was mainly observed in OF compared to other groups, and showed a 13.6-fold increase in OF compared to DF (Fig. 2b). Prosaposin (PSAP) mRNA was slightly increased by 1.9 -fold in OF when compared to DF. Tenascin C (TNC) was induced in GC of OF when compared to DF and SF. ADAM metallopeptidase with thrombospondin type 1 motif 9 (ADAMTS9) found as an EST a

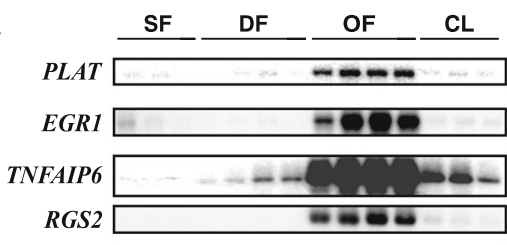

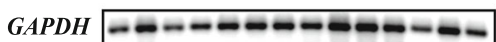

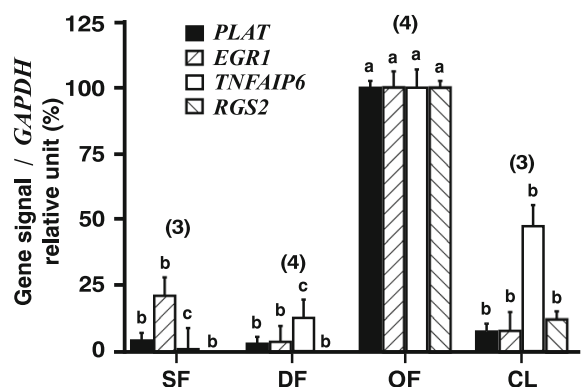

b
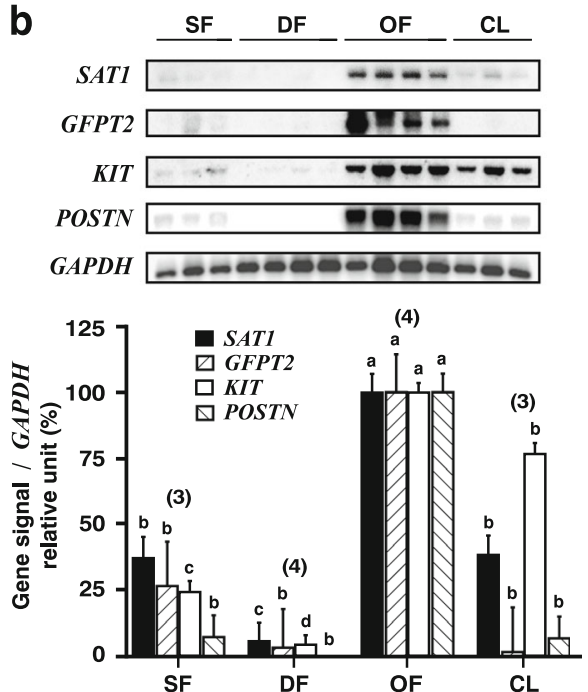

Fig. 1 Analysis of mRNA expression by semiquantitative RT-PCR/Southern blot. Total RNA was extracted from bovine GC collected from 2 to 4 mm small follicles (SF), dominant follicles (DF) at Day 5 of the estrous cycle, ovulatory follicles (OF) collected $24 \mathrm{~h}$ after injection of hCG, and corpora lutea (CL) from Day 5 of the estrous cycle, then used in mRNA expression analyses using semiquantitative RT-PCR/Southern blot analysis. GAPDH was used as a control gene and showed no significant difference in expression between groups. Gene-specific signals were normalized with corresponding GAPDH signals ( $1.8 \mathrm{~kb}$ ) for each sample, and relative values are reported as percent of expression detected in OF. a) Expression of PLAT (2.5 kb) mRNAs was upregulated by 32.8-fold in OF compared with DF $(P<0.0001)$; expression of EGR1 mRNA (2.4 kb) was 24.7-fold higher in OF than in DF $(P<0.0001)$; expression of TNFAIP6 mRNA (1.6 kb) was upregulated by 7.9-fold in OF compared with DF $(P<0.0001)$; and expression of RGS2 mRNA $(1.8 \mathrm{~kb})$ was induced in OF compared with DF $(P<0.0001)$; b) expression of SAT1 (2.5 kb) mRNAs was upregulated by 18 -fold in OF compared with DF $(P<0.0001)$; expression of GFPT2 mRNA (3 kb) was 26.8-fold higher in OF than in DF $(P<0.0029)$; expression of KIT mRNA (5 kb) was upregulated by 23.6-fold in OF compared with DF $(P<0.0001)$; and expression of POSTN mRNA (3.7 kb) was induced in OF compared with DF $(P<0.0001)$. Probability values for each one-way ANOVA analysis are specified above in parentheses. Different letters denote samples that differed significantly $(P<0.05)$ between group means for a specific gene. Data are presented as least-square means \pm SEM, and the number of independent samples per group is indicated in parentheses 
a
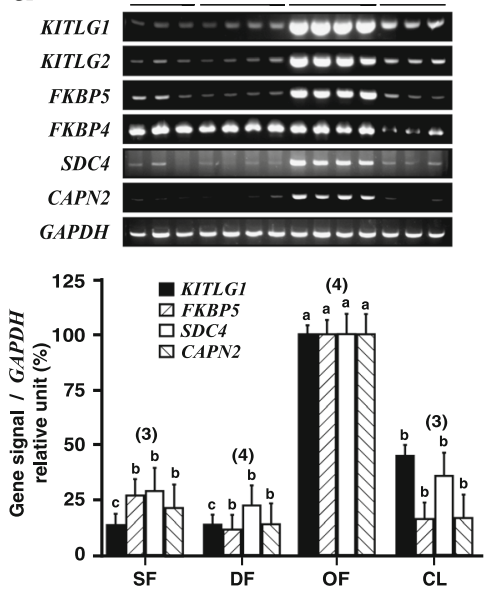

b
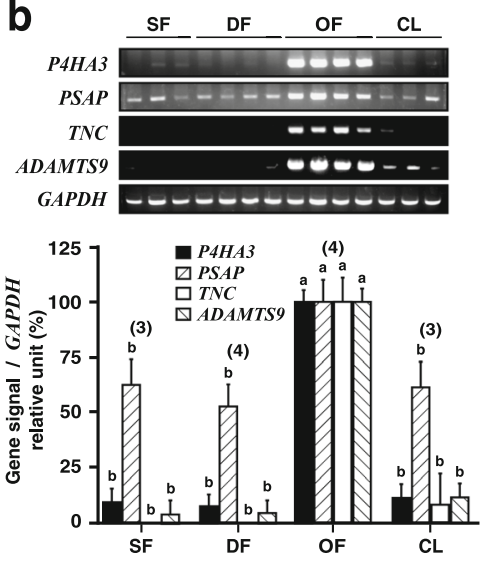
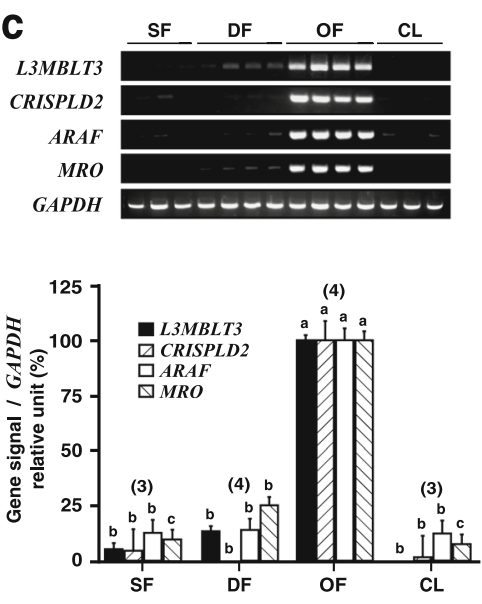

d
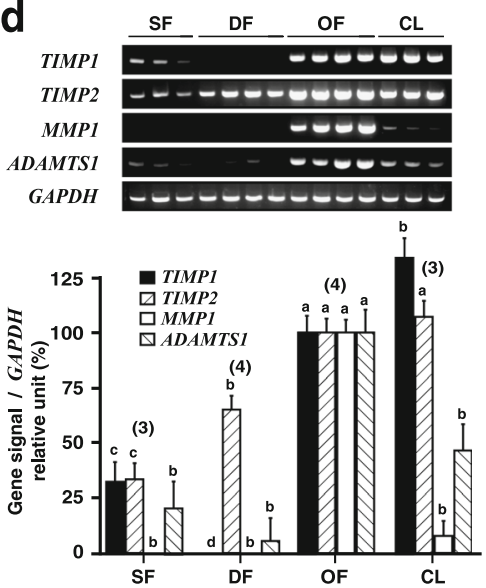

e
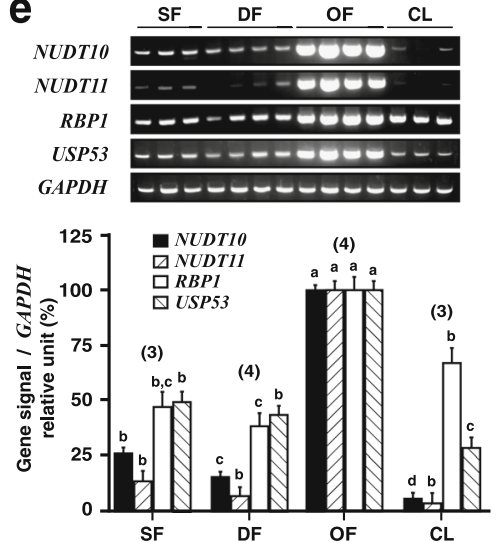

Fig. 2 (See legend on next page.) 


\section{(See figure on previous page.)}

Fig. 2 Analysis of mRNA expression by semiquantitative RT-PCR. Total RNA was extracted from bovine GC collected from 2 to $4 \mathrm{~mm}$ small follicles (SF), dominant follicles (DF) at Day 5 of the estrous cycle, ovulatory follicles (OF) $24 \mathrm{~h}$ after injection of hCG (OF), and corpora lutea (CL) from Day 5 of the estrous cycle, then used in mRNA expression analyses using RT-PCR. GAPDH was used as a control gene and showed no significant differences in expression between groups. Gene-specific RT-PCR amplicons were normalized with corresponding GAPDH (727 bp) amplicons for each sample. a) KITLG1 (587 bp) and KITLG2 (496 bp) mRNA were shown to be upregulated each by 6.7-fold in OF compared with DF ( $\mathrm{P}<0.0001)$; expression of FKBP5 (450 bp) mRNA was increased by 8.6-fold in OF compared with DF $(\mathrm{P}<0.0001)$; FKBP4 (416 bp) mRNA did not differ between follicular stages but was reduced by 2.8-fold in $C L$ when compared to OF ( $<<0.0001$ ); expression of SDC4 (443 bp) mRNA was increased by 4.5-fold in OF compared to DF $(P<0.0005)$; and expression of CAPN2 (453 bp) mRNA was increased by 7.1 -fold in OF compared to DF $(P<0.0002)$; b) P4HA3 (446 bp) mRNA was upregulated by 13.6-fold in OF compared to DF ( $<0.0001)$; PSAP (356 bp) mRNA was increased by 1.9-fold $(P<0.033)$; TNC (419 bp) mRNA was induced in OF compared to DF ( $<<0.0002)$; and expression ADAMTS9 (454 bp) mRNA was increased by 24.1-fold in OF compared to DF (P < 0.0001); c) L3MBLT3 (1825 bp) mRNA was upregulated by 7.5-fold in OF compared to DF $(\mathrm{P}<0.0001)$; CRISPLD2 (493 bp) mRNA was induced in OF compared to SF and DF ( $<<0.0001)$; ARAF (489 bp) mRNA was upregulated by 7.2 -fold in OF compared to DF ( $<$ 0.0001); and MRO (474 bp) mRNA was increased by 4-fold in OF compared to DF (P < 0.0001$)$; d) TIMP1 (487 bp) was induced in OF compared to DF ( $P<0.0001)$; TIMP2 (477 bp) was increased by 1.5 -fold in OF compared to DF ( $<0.0001)$; MMP1 (467 bp) was induced in OF compared to DF and SF ( $<<0.0001$ ); and ADAMTS1 (482 bp) was upregulated by 18-fold in OF compared to DF ( $<<0.0001)$; e) NUDT10 (569 bp) was increased by 6.5-fold in OF compared to DF ( $<<0.0001$ ); NUDT11 (466 bp) was upregulated by 15.2 fold in OF compared to DF ( $P<0.0001)$; RBP1 (444 bp) was increased by 2.6-fold in OF compared to DF $(\mathrm{P}<0.0001)$; USP53 (435 bp) was upregulated by 2.3 -fold in OF compared to DF $(P<0.0001)$. Probability values for each oneway ANOVA analysis are specified above in parentheses. Different letters denote samples that differed significantly $(P<0.05)$ between group means for a specific gene. Data are presented as least-square means \pm SEM, and the number of independent samples per group is indicated in parentheses

corresponding to intron 28 (Table 2) was upregulated by 24.1-fold in OF compared to DF. Expression of the histone methyl-lysine binding protein (L3MBLT3) mRNA showed an increase of 7.5-fold in OF compared to DF whereas no expression was detected in CL (Fig. 2c). Cystein-rich secretory protein LCCL domain containing 2 (CRISPLD2) mRNA was induced in OF when compared to DF. A-Raf proto-oncogene serine/threonine kinase (ARAF) mRNA was upregulated by 7.2-fold in OF compared to DF, and maestro $(M R O)$ mRNA was increased by 4-fold in OF compared to DF. TIMP metallopeptidase inhibitor 1 (TIMP1) was induced in GC of OF when compared to DF whereas TIMP metallopeptidase inhibitor 2 (TIMP2) was upregulated by only 1.5-fold (Fig. 2d). Matrix metallopeptidase 1 (MMP1) was induced in GC of OF when compared to SF and DF, and was reduced in CL. ADAM metallopeptidase with thrombospondin type 1 motif 1 (ADAMTS1) was upregulated by 18 -fold in OF compared to DF. Expression of nudix hydroylase 10 (NUDT10) and nudix hydroxylase 11 (NUDT11) mRNAs where upregulated by 6.5 -fold and 15.2fold, respectively, reaching the lowest level in CL (Fig. 2e). Retinol-binding protein 1 (RBP1) mRNA was upregulated by 2.6-fold in OF, and ubiquitin specific peptidase 53 (USP53) was upregulated by 2.3 -fold.

\section{Characterization of bovine POSTN, CRISPLD2 and L3MBTL3 cDNAs}

Bovine full-length cDNAs for POSTN, CRISPLD2 and L3MBTL3 cDNAs were not previously experimentally characterized in the bovine species. Since only cDNA fragments were obtained from the screening of the OF-DF subtracted library and that potential alternatively spliced isoforms may be expressed, we undertook their characterization in GC to ascertain the identity of the OF-DF cDNA fragments. Bovine
cDNA fragments for POSTN, CRISPLD2 and L3MBTL3 were cloned from the SSH screening of the OF-DF subtracted library as presented in Table 1 , and were used as probes to screen by hybridization size-selected cDNA generated from bovine GC that were collected $24 \mathrm{~h}$ following injection of hCG. The bovine POSTN cDNA consists of 3072 bp (Genbank: AY445072), and is composed of a 5'UTR of $42 \mathrm{bp}$, an ORF of $2511 \mathrm{bp}$ and a 3'-UTR of $519 \mathrm{bp}$ containing two polyadenylation signals followed by a poly $(\mathrm{A})^{+}$tail. The coding region of bovine POSTN cDNA encodes a protein of 836 amino acids, with a theoretical molecular mass $(\mathrm{Mr})$ of $93.1 \mathrm{kDa}$ and an isoelectric point (pI) of 7. Amino acid homology analysis by PsiBlast revealed an overall identity level of $95 \%$ to human (NP_001129406). Bovine POSTN possesses a peptide signal $\left(\mathrm{M}^{1}-\mathrm{A}^{21}\right)$ that may be cleaved between $\mathrm{A}^{21}-\mathrm{N}^{22}$, a cystein-rich domain called EMI domain $\left(\mathrm{G}^{40}-\mathrm{A}^{94}\right)$, and four fasciclin domains $\left(\mathrm{T}^{111}-\mathrm{T}^{231}, \mathrm{E}^{246}-\mathrm{P}^{367}, \mathrm{Q}^{381}-\mathrm{P}^{494}\right.$, $\left.\mathrm{R}^{508}-\mathrm{P}^{630}\right)$. Since five POSTN isoforms were reported in human, we verified by RT-PCR and sequencing if other POSTN isoforms were expressed in GC using primers targeting the entire ORF (Table 1). A single full-length cDNA of $2511 \mathrm{pb}$ was characterized.

The bovine CRISPLD2 cDNA consists of 4020 bp (Genbank: AY369781), and is composed of a $5^{\prime}$-UTR of $210 \mathrm{bp}$, an ORF of $1488 \mathrm{bp}$, and a 3'-UTR of $2322 \mathrm{bp}$ containing six AU-rich elements (ATTTA) as well as two polyadenylation signals followed by a poly $(\mathrm{A})^{+}$tail. The coding region of CRISPLD2 CDNA encodes a protein of 496 amino acids, with a theoretical Mr. of $55.6 \mathrm{kDa}$, pI of 8.2 , and an overall identity level of $83 \%$ to human (NP_113664) and 76\% to mouse (NP_084485) proteins. Bovine CRISPLD2 protein possesses a peptide signal $\left(\mathrm{M}^{1}\right.$ $\mathrm{G}^{22}$ ) that may be cleaved between $\mathrm{G}^{22}-\mathrm{F}^{23}$, a cystein-rich 
secretory protein, antigen 5 , and pathogenesis-related protein (known as CAP domain; $\mathrm{L}^{60}-\mathrm{Y}^{200}$ ) and two Limulus factor C, Coch-5b2 and Lgl1 domains (LCCL-1: $\mathrm{V}^{287}-\mathrm{F}^{378}$; LCCL-2: $\mathrm{L}^{388}-\mathrm{T}^{482}$ ).

The bovine L3MBTL3 cDNA characterized from GC consists of 3892 bp (Genbank: AY437805), and is composed of a $5^{\prime}$-UTR of $205 \mathrm{bp}$, an open reading frame (ORF) of $2322 \mathrm{bp}$ and a 3'-UTR of 1570 bp containing three AU-rich elements (ATTTA) as well as two polyadenylation signals followed by a poly $(\mathrm{A})^{+}$tail. The coding region of bovine $L 3 M B T L 3$ CDNA encodes a protein of 773 amino acids, with a theoretical $\mathrm{Mr}$. of $87.5 \mathrm{kDa}$, pI of 6, and an overall identity level of $96 \%$ to human (GenBank: NP_115814) and 87\% to mouse (NP_766375) proteins. Since the bovine protein expressed in GC was missing the last seven amino acids at its carboxyterminal end, corresponding to ${ }^{774} \mathrm{KNSHNEL}^{780}$ when compared to human protein, we verified by RT-PCR and sequencing if other L3MBTL3 isoforms would be expressed in GC by using primers targeting the 3 '-end of the open reading frame (Table 1). In parallel, RT-PCR analysis was performed using RNA extracted from a bovine endometrial epithelial and glandular cell line (Endo 8.3; [12]. In GC, a single alternatively spliced transcript was observed coding for the 773 amino acids protein that we previously characterized using the size selected cDNA library screening technique. This truncated L3MBTL3 isoform is referred as transcript 2 (GenBank: AY437805). Conversely, a single transcript was also observed in the endometrial cell line that corresponded to the complete protein of 780 amino acids with a theoretical Mr. of $88.3 \mathrm{kDa}$ and $\mathrm{pI}$ of 6.1, referred as L3MBTL3 transcript 1 (GenBank: KT881243). Bovine L3MBTL3 protein isoforms expressed in GC and the endometrial cell line possesses three malignant brain tumor (MBT) repeat domains (MBT-1: $\mathrm{M}^{268}-\mathrm{K}^{336}$; MBT2: $\mathrm{M}^{375}-\mathrm{Y}^{442}$; MBT-3: $\left.\mathrm{M}^{479}-\mathrm{P}^{543}\right), \mathrm{C} 2 \mathrm{HC}$ zinc finger domain $\left(\mathrm{G}^{557}-\mathrm{S}^{586}\right)$ and a sterile alpha motif domain (SAM; $\left.S^{706}-K^{770}\right)$.

\section{Discussion}

The preovulatory LH surge from the pituitary gland activates $\mathrm{LH}$ receptors on $\mathrm{GC}$ and theca cells, and induces a cascade of events in the dominant preovulatory follicle. They include the formation of the expanded hyaluronanrich cumulus oophorus extracellular matrix (ECM), the release of a competent oocyte following the degradation/ rupture of the follicular wall's ECM, and the differentiation of GC and theca cells into luteal cells that contribute to corpus luteum formation. These processes are controlled by the expression of several genes that are either up- or downregulated in a temporally and spatially distinct fashion. However, the molecular mechanisms regulating the developmental transition of a dominant preovulatory follicle into an ovulatory follicle are not fully understood [2]. Identifying the precise subset of genes involved in these processes is essential to fully comprehend the cascade of events leading to ovulation and luteinization of the follicle, and will likely contribute to a better control of fertility.

We elected to use the SSH method for the identification of differentially expressed genes. This approach involved the screening by hybridization of the OF-DF subtracted GC cDNA library, which first allowed the selection of cDNAs based on differences in their signal intensities, and then their identification by DNA sequencing and further validation by semiquantitative RT-PCR. The genes upregulated in GC by hCG and identified by $\mathrm{SSH}$ in this study corroborate well those identified by microarray using a physiological model of endogenous LH release [4]. Screening the OF-DF subtracted cDNA library allowed identification of genes such as ADAMTS1 [13, 14], EGR1 [15], MMP1 [16], PLAT [16-18], PTGES [19], PTGS2 [10], PTX3 [4], TIMP1 [16], TIMP2 [20] and TNFAIP6 [21] that had previously been shown to be differentially expressed in GC of bovine ovulatory follicles compared to that of dominant preovulatory follicles. The identification of these genes validates the physiological model and the analytical approach used herein. Moreover, from the list of genes identified in Table 2, we also have previously investigated and confirmed the spatiotemporal induction of PLA2G4A [22] and CAV1 [23] at the mRNA and protein levels, and of VNN2 [24] and RGS2 [25] at the mRNA level, in GC collected at $0,6,12,18$, and $24 \mathrm{~h}$ post-hCG injection.

Of particular interest, FKBP5 and FKBP4 proteins, also known as FKBP51 and FKBP52, are nuclear receptor cochaperones regulating cellular trafficking and activity of steroid hormone receptors such as the progesterone and glucocorticoid receptors. These co-chaperones compete for a common binding site on the heat shock protein 90 (Hsp90) that is complexed to steroid receptors. The level of FKBP4 and FKBP5 complexed to Hsp90 is determined by the abundance and affinity of each co-chaperone. FKBP5 is found in greater amount complexed to the progesterone receptor, as compared to FKBP4, and FKBP5 reduces, whereas FKBP4 increases, the binding affinity of the progesterone receptor toward its natural ligand [26, 27]. Interestingly, the presence of high levels of FKBP5 protein in various tissues of squirrel monkey primates has been identified as a potential cause of progesterone resistance in this species [28]. In the present study, we show that the expression of FKBP4 mRNA in $\mathrm{GC}$ does not differ in follicles larger than $2 \mathrm{~mm}$ up to ovulation. FKBP4 may potentiate the action of the progesterone receptor in GC since knockout mice for FKBP4 have a reduced number of ovulation [29]. 
Conversely, expression of FKBP5 mRNA increased in GC of hCG-induced ovulatory follicles. Since progesterone concentration increases in follicle following the LH/ hCG preovulatory surge, and progesterone stimulates the transcription of FKBP5 [30], the increase of FKBP5 expression in bovine GC following the LH/hCG surge may represent a short negative feedback loop involved in attenuating GC progesterone responsiveness. Likewise, FKBP5 as a scaffolding protein was recently shown to recruit the phosphatase PHLPP to facilitate dephosphorylation of AKT and its downstream target p38MAPK $\alpha$ (also known as MAPK14), which in turn decreases activation of the glucocorticoid receptor [31-33]. A similar mechanism may be associated with the progesterone receptor in GC after the LH/hCG surge. Indeed, it is known that phosphorylation of AKT/p38MAPK $\alpha$ is increased in GC by the activation of the EGFR following binding of the EGF-like proteins, epiregulin (EREG) and amphiregulin (AREG) [34], and that EREG and AREG are induced in bovine GC after the LH/hCG surge [35, 36]. Such EGFR-dependent activation of the AKT/ p38MAPK $\alpha$ pathway $[34,36]$ likely contributes to the phosphorylation and activation of the progesterone receptor [37]. Based on these observations and our findings, we hypothesize that the FKBP5 increase in bovine GC following the preovulatory LH surge may limit the EGFR-dependent AKT/p38MAPK $\alpha$ phosphorylation, and thus reduce progesterone receptor phosphorylation and activation, thereby attenuating GC progesterone responsiveness during ovulation and initial luteinization. The demonstration of such regulatory mechanism will require further investigations.

In addition to the list genes whose expression and/or role in ovulation has been in part or clearly determined, we have reported the cDNA characterization and the increased expression of POSTN, CRISPLD2 and L3MBTL3 mRNA in hCG-induced OF, and have conceived their possible function in the ovulatory follicle from what is known in the literature. We found that POSTN mRNA was induced by hCG in GC of OF but was absent in DF, in keeping with findings by Christenson et al. [4]. Only a single full-length POSTN mRNA was observed in hCG-stimulated bovine GC in the present study, as compared to the five POSTN isoforms identified in human (review: [38]). The possibility that POSTN could undergo post-translational modifications in GC will require further investigation [39]. POSTN is a secreted modular glycoprotein that interacts with various proteins of the ECM, growth factors and integrins. As an ECM protein, POSTN acts as an adhesive protein, binding to collagen I-V and fibronectin through its EMI domain, and to tenascin-C (TNC) through its FAS1 domains, to establish an interlaced ECM architecture. Thus, POSTN contributes to fibrillogenesis during normal tissue development, and tissue remodeling associated with various diseases, wound repair, inflammation and cancer [38]. Interestingly, we observed a concomitant increase in TNC and POSTN mRNAs in GC at ovulation, a coordinated expression also shown to be induced by mechanical stress in fibroblasts [40]. POSTN is known to interact with TNC, a complex disulfide-linked hexameric glycoprotein, to promote its incorporation to other ECM proteins such as collagen, fibronectin and heparan sulfate glycosaminoglycans [41]. POSTN is also recognized as a matricellular protein, a class of ECM proteins that promote non-structural roles such as cell adhesion, migration, proliferation, differentiation and survival $[38,39]$. For these functions, POSTN interacts with integrins, that are the major membrane receptors mediating adhesion to the ECM, which lead to intracellular activation of the PI3K/AKT and focal adhesion kinase signaling pathways [38, 42, 43]. Such functions and activation could be present in GC since GC do express integrins [44]. Lastly, the ability of POSTN to induce angiogenesis by increasing VEGF receptor (KDR) expression in endothelial cells [43] may also be relevant to the marked neovascularization observed during the early stage of corpus luteum formation. Thus, the LH/ hCG-dependent induction of POSTN mRNA in GC suggests its potential role as a key factor involved in various functions associated with ovulation, including GC survival, migration and luteinization, as well as angiogenesis and tissue remodeling required in the formation of the corpus luteum.

The role of CRISPLD2 in the female reproductive tract remains largely unexplored and, to our knowledge, this study is the first to document the hCG-dependent induction of CRISPLD2 mRNA in GC of OF. CRISPLD2 is a member of the CAP (Cysteine-rich secretory proteins, Antigen 5, and Pathogenesis-related 1 proteins) superfamily of proteins, and is also known as CAPLD2. It is a secreted protein containing LCCL tandem domains that have been associated with multiple functions such as cell differentiation, migration, inflammation and immunity (review:[45]). CRISPLD2 expression has been involved in lung morphogenesis [46], kidney development [47], and in craniofacial morphogenesis [48]. Recently, it was shown to regulate proliferation, apoptosis, and migration of fetal lung fibroblasts, to contribute to mesenchymalepithelial signaling, and to enhance wound repair [46]. In the latter study, CRISPLD2 was associated with the abnormal expression of multiple extracellular matrix (ECM) genes that modulate lung development and repair. Since a parallel can be drawn with the ovulatory process in which multiple ECM proteins and ECM modifying enzymes are induced (Table 2), we suggest that CRISPLD2 may interact with these proteins and modifying enzymes during ovulation. Interestingly, 
CRISPLD2 is regulated by progesterone (P4) and its receptor (PGR) in the uterus, its expression is high during decidualization, constitutive during pregnancy and is dysregulated in patients with endometriosis [49]. A similar P4/PGR-dependent regulation of CRISPLD2 gene expression has been observed in rat granulosa cells [50]. However, despite the fact that the bovine CRISPLD2 proximal promoter does not harbor a PGR response element, the effect could be indirect as PGR is known to enhance functional activity of SP1 and GC-rich regions $[51,52]$, which are present in the bovine proximal promoter. CRISPLD2 has also been identified as a potential inhibitory modulator of the inflammatory and immune response, since glucocorticoids and interleukin-1 $\beta$ (IL1$\beta$ ) increase CRISPLD2 mRNA and protein expression in airway smooth muscle cells, and CRISPLD2 modulates the expression of IL1- $\beta$ responsive inflammatory genes such as IL6 and IL8 $[53,54]$. Considering that ovulation is an acute inflammatory reaction and that the LH surge induces IL1- $\beta$ in GC (review: [55]), another role for CRISPLD2 during ovulation may be to limit the inflammatory reaction. Thus, through its action on ECM proteins and modifying enzymes or the control of the inflammatory reaction, we propose that the induction of CRISPLD2 in GC of OF likely plays a key role in follicular rupture and ECM remodeling. Since CRISPLD2 knockout mice die during embryogenesis [56], a tissuespecific conditional knockout approach may be more appropriate to ultimately document the significance of ovarian CRISPLD2 gene expression.

Expression of L3MBTL3 mRNA in GC was 7.5 -fold stronger in $\mathrm{OF}$ as compared to DF but this expression was extinguished in $\mathrm{CL}$, suggesting a potential role for L3MBTL3 in LH surge/hCG-induced events, such as ovulation and initial luteinization. L3MBTL3 is known to interact with the polycomb group repressive complex 1 (PRC1) family of proteins that maintains genes in a transcriptionally repressive state by modification of the chromatin [review: 57-58]. L3MBTL3 localizes into foci of the DNA-rich regions of the nucleus, and is classified as a chromatin histone methyllysine reader protein [57]. Methyllysine acts as docking site for specific reader proteins that alter chromatin structure to control various cellular processes. Proteins containing MBT domain such as L3MBTL3, which holds three MBT domains, are known to dimerize and to selectively recognize sequence specific mono and dimethyl-lysine residues within histone tails $[57,58]$. This allows to target chromatin regulatory complexes, such as PRC1, to appropriate genomic loci, and has been functionally link to repression of gene expression. Moreover, the roles of MBT proteins have been associated with regulation of mitosis, tumor suppression, maintenance of cell identity and body pattern during development $[59,60]$. In addition to the three
MBT domains, L3MBTL3 harbors a SAM domain known to confer protein-protein interaction features and to act as a scaffolding protein for homo- or heterodimerization [58, 61]. Interestingly, we have shown in the present study that bovine $L 3 M B T L 3$ mRNA is alternatively spliced in GC, as compared to the complete mRNA expressed in bovine endometrial cells. To our knowledge, this is the first study to report an alternatively spliced isoform of L3MBTL3 in mammalian species that results in a truncated open reading frame. The missing last seven amino acids, ${ }^{774} \mathrm{KNSHNEL}^{780}$, of L3MBTL3 isoform 2 are located within the carboxyterminal end following the SAM domain $\left.{ }^{706} \mathrm{~S}-\mathrm{K}^{770}\right)$ known to confer protein/protein interactions [61]. These last amino acids $\left({ }^{774} \mathrm{~K}-\mathrm{L}^{780}\right)$ are well conserved in all mammalian species, which likely indicates a fundamental function for these amino acids in the epigenetic control of gene expression. Taken together, we hypothesize that the increase of L3MBTL3 expression in GC of ovulatory follicles may be necessary to silence specific genes that would otherwise negatively impact ovulation and/or initiation of luteinization. Additional studies will be required to unravel the physiological role of L3MBTL3 in $\mathrm{GC}$ function, and to investigate the functional significance of the C-terminal truncated L3MBTL3 spliced variant.

\section{Conclusions}

In this study, we have identified several genes whose transcripts levels were increased following hCG injection. While the role of many of these genes is well documented, the exact function of genes such as FKBP5, POSTN, CRISPLD2, L3MBTL3 and others (Table 2) in the ovulatory and luteinization processes remain to be fully explored.

\section{Additional file}

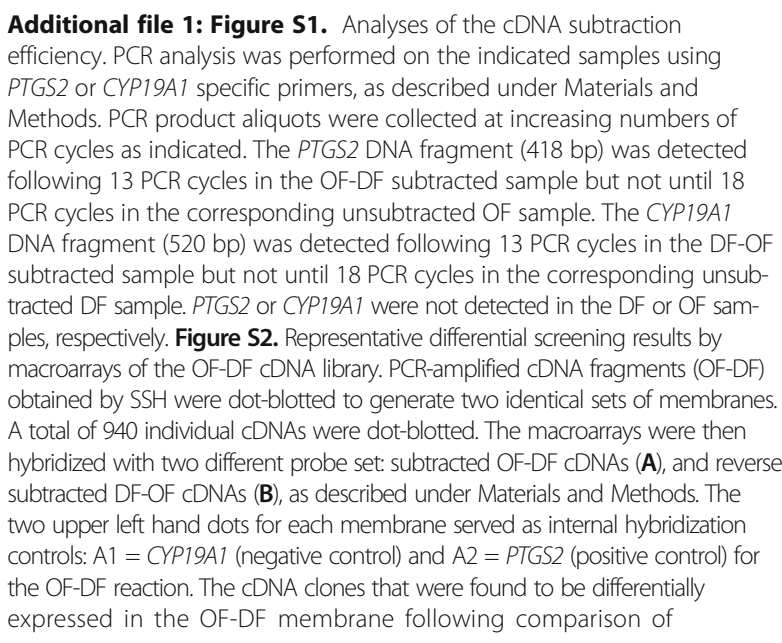


hybridization signals among the corresponding spots of the two membranes were further characterized by sequencing. (PDF $275 \mathrm{~kb}$ )

\section{Abbreviations}

CL: Corpus luteum; DF: Dominant follicles; eCG: equine chorionic gonadotropin; ECM: Extracellular matrix; GC: Granulosa cells; hCG: Human chorionic gonadotropin; LH: Luteinizing hormone; OF: Ovulatory follicles; OFDF or DF-OF: Granulosa cell subtracted cDNA library; SF: Small follicles; SSH: Suppression subtractive hybridization

\section{Acknowledgments}

The authors would like to sincerely thank Isabelle Daneau for the sequencing reactions.

\section{Funding}

This work was supported by the Natural Sciences and Engineering Research Council of Canada Discovery grant \#104199 (JGL) and by internal funds from Université de Montréal (KN).

\section{Availability of data and materials}

All data generated or analysed during this study are included in this published article.

\section{Authors' contributions}

JGL, MND, KN and JS participated in the design of the study and collect of samples. MND, VL, KN and JGL performed the laboratory work and data analyses. JGL, MND, KN, JS drafted the manuscript. All authors read and approved the final manuscript.

\section{Ethics approval and consent to participate}

The experiments were approved by the Animal Ethics Committee of the Faculty of Veterinary Medicine of the Université de Montréal.

\section{Consent for publication}

Not applicable.

\section{Competing interests}

The authors declare that they have no competing interests.

\section{Publisher's Note}

Springer Nature remains neutral with regard to jurisdictional claims in published maps and institutional affiliations.

\section{Author details}

${ }^{1}$ Centre de recherche en reproduction et fertilité, Faculté de médecine vétérinaire, Université de Montréal, 3200 Sicotte, St-Hyacinthe, Québec J2S 2M2, Canada. Institut Sénégalais de Recherches Agricoles (ISRA) Laboratoire National de l'Elevage et de Recherches Vétérinaires (LNERV), BP 2057 Dakar-Hann, Sénégal.

Received: 12 September 2017 Accepted: 16 October 2017 Published online: 03 November 2017

\section{References}

1. Mihm M, Evans AC. Mechanisms for dominant follicle selection in monovulatory species: a comparison of morphological, endocrine and intraovarian events in cows, mares and women. Reprod Domest Anim. 2008;43(Suppl 2):48-56.

2. Richards JS. Genetics of ovulation. Semin Reprod Med. 2007;25(4):235-42.

3. Ndiaye K, Fayad T, Silversides DW, Sirois J, Lussier JG. Identification of downregulated messenger RNAs in bovine granulosa cells of dominant follicles following stimulation with human chorionic gonadotropin. Biol Reprod. 2005;73(2):324-33.

4. Christenson LK, Gunewardena S, Hong X, Spitschak M, Baufeld A, Vanselow J. Research resource: preovulatory LH surge effects on follicular theca and granulosa transcriptomes. Mol Endocrinol. 2013;27(7):1153-71.

5. Espey LL, Richards JS. Temporal and spatial patterns of ovarian gene transcription following an ovulatory dose of gonadotropin in the rat. Biol Reprod. 2002;67(6):1662-70.
6. Li Q, Jimenez-Krassel F, Ireland JJ, Smith GW. Gene expression profiling of bovine preovulatory follicles: gonadotropin surge and prostanoiddependent up-regulation of genes potentially linked to the ovulatory process. Reproduction. 2009;137(2):297-307.

7. Gilbert I, Robert C, Dieleman S, Blondin P, Sirard MA. Transcriptional effect of the LH surge in bovine granulosa cells during the peri-ovulation period. Reproduction. 2011;141(2):193-205.

8. Fayad T, Lévesque V, Sirois J, Silversides DW, Lussier JG. Gene expression profiling of differentially expressed genes in granulosa cells of bovine dominant follicles using suppression subtractive hybridization. Biol Reprod. 2004;70(2):523-33.

9. Bédard J, Brûlé S, Price CA, Silversides DW, Lussier JG. Serine protease inhibitor-E2 (SERPINE2) is differentially expressed in granulosa cells of dominant follicle in cattle. Mol Reprod Dev. 2003;64(2):152-65.

10. Sirois J. Induction of prostaglandin endoperoxide synthase-2 by human chorionic gonadotropin in bovine preovulatory follicles in vivo. Endocrinology. 1994; 135(3):841-8.

11. Lévesque V, Fayad T, Ndiaye K, Nahé Diouf M, Lussier JG. Size-selection of cDNA librairies for the cloning of cDNAs after suppression subtractive hybridization. BioTechniques. 2003;35(1):72-8.

12. Brûlé S, Sayasith K, Sirois J, Silversides DW, Lussier JG. Structure of the bovine VASAP-60/PRKCSH gene, functional analysis of the promoter, and gene expression analysis. Gene. 2007;391(1-2):63-75.

13. Madan P, Bridges PJ, Komar CM, Beristain AG, Rajamahendran R, Fortune JE, MacCalman CD. Expression of messenger RNA for ADAMTS subtypes changes in the periovulatory follicle after the gonadotropin surge and during luteal development and regression in cattle. Biol Reprod. 2003;69(5):1506-14.

14. Sayasith K, Lussier J, Sirois J. Molecular characterization and transcriptional regulation of a disintegrin and metaloproteinase with thrombospondin motif 1 (ADAMTS1) in bovine preovulatory follicles. Endocrinology. 2013;154(8):2857-69.

15. Sayasith K, Brown KA, Lussier JG, Doré M, Sirois J. Characterization of bovine early growth response factor-1 and its gonadotropin-dependent regulation in ovarian follicles prior to ovulation. J Mol Endocrinol. 2006;37(2):239-50.

16. Berisha B, Steffl M, Welter $H$, Klie H, Meyer HH, Schams D, Amselgruber W. Effect of the luteinising hormone surge on regulation of vascular endothelial growth factor and extracellular matrix-degrading proteinases and their inhibitors in bovine follicles. Reprod Fertil Dev. 2008;20(2):258-68.

17. Dow MPD, Bakke LJ, Cassar CA, Peters MW, Pursley JR, Smith GW. Gonadotropin surge-induced up-regulation of the plasminogen activators (tissue plasminogen activator and urokinase plasminogen activator) and the urokinase plasminogen activator receptor within bovine periovulatory follicular and luteal tissue. Biol Reprod. 2002;66(5):1413-21.

18. Li Q, Jimenez-Krassel F, Kobayashi Y, Ireland JJ, Smith GW. Effect of intrafollicular indomethacin injection on gonadotropin surge-induced expression of select extracellular matrix degrading enzymes and their inhibitors in bovine preovulatory follicles. Reproduction. 2006;131(3):533-43.

19. Filion F, Bouchard N, Goff AK, Lussier JG, Sirois J. Molecular cloning and induction of bovine prostaglandin $\mathrm{E}$ synthase by gonadotropins in ovarian follicles prior to ovulation in vivo. J Biol Chem. 2001;276(36):34323-30.

20. Bakke LJ, Dow MPD, Cassar CA, Peters MW, Pursley JR, Smith GW. Effect of the preovulatory gonadotropin surge on matrix metalloproteinase (MMP)14, MMP-2, and tissue inhibitor of metalloproteinases-2 expression within bovine periovulatory follicular and luteal tissue. Biol Reprod. 2002;66(6):1627-34.

21. Sayasith K, Bouchard N, Doré M, Sirois J. Regulation of bovine tumor necrosis factor-alpha-induced protein 6 in ovarian follicles during the ovulatory process and promoter activation in granulosa cells. Endocrinology. 2008:149(12):6213-25.

22. Diouf MN, Sayasith K, Lefebvre R, Silversides DW, Sirois J, Lussier JG. Expression of phospholipase A2 group IVA (PLA2G4A) is upregulated by human chorionic gonadotropin in bovine granulosa cells of ovulatory follicles. Biol Reprod. 2006;74(6):1096-103.

23. Diouf MN, Lefebvre R, Silversides DW, Sirois J, Lussier JG. Induction of alpha-caveolin1 (alphaCAV1) expression in bovine granulosa cells in response to an ovulatory dose of human chorionic gonadotropin. Mol Reprod Dev. 2006;73(11):1353-60.

24. Sayasith K, Sirois J, Lussier JG. Expression, regulation, and promoter activation of Vanin-2 (VNN2) in bovine follicles prior to ovulation. Biol Reprod. 2013;89(4):98.

25. Sayasith K, Sirois J, Lussier JG. Expression and regulation of regulator of G-protein signaling protein-2 (RGS2) in equine and bovine follicles prior to ovulation: molecular characterization of RGS2 transactivation in bovine granulosa cells. Bio Reprod. 2014;91(6):139. 
26. Smith DF, Toft DO. Minireview: the intersection of steroid receptors with molecular chaperones: observations and questions. Mol Endocrinol. 2008; 22(10):2229-40.

27. Storer CL, Dickkey CA, Galigniana MD, Rein T, Cox MB. FKBP51 and FKBP52 in signaling and disease. Trends Endocrinol Metab. 2011;22(12):481-90.

28. Hubler TR, Denny WB, Valentine DL, Cheung-Flynn J, Smith DF, Scammell JG. The FK506-binding immunophilin FKBP51 is transcriptionally regulated by progestin and attenuates progestin responsiveness. Endocrinology. 2003; 144(6):2380-7.

29. Yang Z, Wolf IM, Chen H, Periyasamy S, Chen Z, Yong W, Shi S, Zhao W, Xu J, Srivastava A, Sánchez ER, Shou W. FK506-binding protein 52 is essential to uterine reproductive physiology controlled by the progesterone receptor a isoform. Mol Endocrinol. 2006:20(11):2682-94.

30. Magklara A, Smith CL. A composite intronic element directs dynamic binding of the progesterone receptor and GATA-2. Mol Endocrinol. 2009; 23(1):61-73

31. Pei H, Li L, Fridley BL, Jenkins GD, Kalari KR, Lingle W, Petersen G, Lou Z, Wang L. FKBP51 affects cancer cell response to chemotherapy by negatively regulating AKT. Cancer Cell. 2009;16(3):259-66.

32. Fabian AK, März A, Neimanis S, Biondi RM, Kozany C, Hausch F. InterAKTions with FKBPs - mutational and pharmacological exploration. PLoS One. 2013; 8(2):e57508.

33. Stechschulte LA, TDJr H, Ghanem SS, Shou W, Najjar SM, Sanchez ER. FKBP51 reciprocally regulates GRa and PPARy activation via the Akt-p38 pathway. Mol Endocrinol. 2014;28(8):1254-64.

34. Liu Z, Fan HY, Wang Y, Richards JS. Targeted disruption of MAPK14 (p38MAPKa) in granulosa cells and cumulus cells causes cell-specific changes in gene expression profiles that rescue COC expansion and maintain fertility. Mol Endocrinol. 2010;24(9):1794-804.

35. Sayasith K, Lussier J, Doré M, Sirois J. Human chorionic gonadotropindependent up-regulation of epiregulin and amphiregulin in equine and bovine follicles during the ovulatory process. Gen Comp Endocrinol. 2013;180:39-47.

36. Mack EM, Smith JE, Kurz SG, Wood JR. CAMP-dependent regulation of ovulatory response genes is amplified by IGF1 due to synergistic effects on Akt phosphorylation and NF-kB transcription factors. Reproduction. 2012; 144(5):595-602.

37. Hagan CR, Daniel AR, Dressing GE, Lange CA. Role of phosphorylation in progesterone receptor signaling and specificity. Mol Cell Endocrinol. 2012; 357(1-2):43-9.

38. Sirica AE, Almenara JA, Li C. Periostin in intrahepatic cholangiocarcinoma: pathological insights and clinical implications. Exp Mol Pathol. 2014;97(3):515-24.

39. Kudo A. Periostin in fibrillogenesis for tissue regeneration: periostin actions inside and outside the cell. Cell Mol Life Sci. 2011;68(19):3201-7.

40. Chiquet M, Gelman L, Lutz R, Maier S. From mechanotransduction of extracellular matrix gene expression in fibroblasts. Biochim Biophys Acta. 2009;1793(5):911-20.

41. Kii I, Nishiyama T, Li M, Matsumoto K, Saito M, Amizuka N, Kudo A. Incorporation of tenascin-C into the extracellular matrix by periostin underlies an extracellular meshwork architecture. J Biol Chem. 2010;285(3):2028-39.

42. Gillan L, Matei D, Fishman DA, Gerbin CS, Karlan BY, Chang DD. Periostin secreted by epithelial ovarian carcinoma is a ligand for alpha(V) beta(3) and alpha(V) beta(5) integrins and promotes cell motility. Cancer Res. 2002 62(18):5358-64.

43. Ruan K, Bao S, Ouyang G. The multifaceted role of periostin in tumorigenesis. Cell Mol Life Sci. 2009;66(14):2219-30.

44. Monniaux D, Huet-Calderwood C, Le Bellego F, Fabre S, Monget P, Calderwood DA. Integrins in the ovary. Semin Reprod Med. 2006;24(4):251-61.

45. Gibbs GM, Roelants K, O'Bryan MK. The CAP Superfamily: Cysteine-rich secretory proteins, antigen 5, and pathogenesis-related 1 proteins-roles in reproduction, cancer, and immune defense. Endocr Rev. 2008;29(7):865-97.

46. Zhang H, Sweezey NB, Kaplan F. LGL1 modulates proliferation, apoptosis, and migration of human fetal lung fibroblasts. Am J Phys Lung Cell Mol Phys. 2015;308(4):L391-402

47. Quinlan J, Kaplan F, Sweezey N, Goodyer P. LGL1, a novel branching morphogen in developing kidney, is induced by retinoic acid. Am J Physiol Ren Physiol. 2007;293(4):F987-93.

48. Swindell EC, Yuan Q, Maili LE, Tandon B, Wagner DS, Hecht JT. Crispld2 is required for neural crest cell migration and cell viability during zebrafish craniofacial development. Genesis. 2015;53(10):660-7.

49. Yoo J-Y, Shin H, Kim TH, Choi W-S, Ferguson SD, Fazleabas AT, Young SL, Lessey BA, Ha U-H, Jeong J-W. CRISPLD2 is a target of progesterone receptor and its expression is decreased in women with endometriosis. PLoS One. 2014:9(6):e100481.

50. Sriraman V, Sinha M, Richards JS. Progesterone receptor-induced gene expression in primary mouse granulosa cell cultures. Biol Reprod. 2010;82(2):402-12.

51. Doyle KM, Russell DL, Sriraman V, Richards JS. Coordinate transcription of the ADAMTS-1 gene by luteinizing hormone and progesterone receptor. Mol Endocrinol. 2004;18(10):2463-78.

52. Shimada M, Yanai Y, Okazaki T, Yamashita Y, Sriraman V, Wilson MC, Richards JS. Synaptosomal-associated protein 25 gene expression is hormonally regulated during ovulation and is involved in cytokine/chemokine exocytosis from granulosa cells. Mol Endocrinol. 2007;21(10):2487-502.

53. Himes BE, Jiang X, Wagner P, Hu R, Wang Q, Klanderman B, Whitaker RM, Duan Q, Lasky-Su J, Nikolos C, Jester W, Johnson M, Panettieri RA Jr, Tantisira KG, Weiss ST, Lu Q. RNA-Seq Transcriptome profiling identifies CRISPLD2 as a glucocorticoid responsive gene that modulates cytokine function in airway smooth muscle cells. PLoS One. 2014;9(6):e99625.

54. Zhang H, Kho AT, Wu Q, Halayko AJ, Limbert Rempel K, Chase RP, Sweezey NB, Weiss ST, Kaplan F. CRISPLD2 (LGL1) inhibits proinflammatory mediators in human fetal, adult, and COPD lung fibroblasts and epithelial cells. Phys Rep. 2016:4(17):e12942

55. Gérard N, Caillaud M, Martoriati A, Goudet G, Lalmanach A-C. The interleukin-1 system and female reproduction. J Endocrinol. 2004;180(2):203-12

56. Lan J, Ribeiro L, Mandeville I, Nadeau K, Bao T, Cornejo S, Sweezey NB, Kaplan F. Inflammatory cytokines, goblet cell hyperplasia and altered lung mechanics in Lgl1+/- mice. Respir Res. 2009;10:83.

57. James LI, Barsyte-Lovejoy D, Zhong N, Krichevsky L, Korboukh VK, Herold MJ, MacNevin CJ, Norris JL, Sagum CA, Tempel W, Marcon E, Guo H, Gao C, Huang X-P, Duan S, Emili A, Greenblatt JF, Kireev DB, Jin J, Janzen WP, Brown PJ, Bedford MT, Arrowsmith CH, Frye SV. Discovery of a chemical probe for the L3MBTL3 methyl-lysine reader domain. Nat Chem Biol. 2013; 9(3):184-91.

58. Baughman BM, Pattenden SG, Norris JL, James LI, Frye SV. The L3MBTL3 methyl-lysine reader domain functions as a dimer. ASC Chem Biol. 2016; 11(3):722-8

59. Bonasio R, Lecona E, Reinberg D. MBT domain proteins in development and disease. Semin Cell Dev Biol. 2010;21(2):221-30.

60. Nady N, Krichevsky L, Zhong N, Duan S, Tempel W, Amaya MF, Ravichandran M, Arrowsmith $\mathrm{CH}$. Histone recognition by human malignant brain tumor domains. J Mol Biol. 2012;423(5):702-18.

61. Knight MJ, Leettola C, Gingery M, Hao L, Bowie JU. A human sterile alpha motif domain polymerizome. Protein Sci. 2011:20(10):1697-706.

\section{Submit your next manuscript to BioMed Central and we will help you at every step:}

- We accept pre-submission inquiries

- Our selector tool helps you to find the most relevant journal

- We provide round the clock customer support

- Convenient online submission

- Thorough peer review

- Inclusion in PubMed and all major indexing services

- Maximum visibility for your research

Submit your manuscript at www.biomedcentral.com/submit
) Biomed Central 